\title{
BUSINESS ACCOUNTING MANAGEMENT IN UKRAINE UNDER THE CONDITIONS OF EUROPEAN INTEGRATION
}

\author{
Viktoriya Rozhelyuk' ${ }^{1}$, Vita Semanyuk ${ }^{2}$, Taras Burdeniuk ${ }^{3}$
}

\begin{abstract}
The purpose of the paper is the aggregation of theoretical, organizational, and methodological concepts of the information economy from the position of its impact on accounting system at processing plants to prove the directions of improvement of its components according to the requirements of modern management. Methodology. The research of the concept of "information" gave the possibility to define the absence of scientific view on this issue. We suggest that talking about information we should understand the processed data including the system of accounting, which reduce the uncertainty of users. Information for management has not yet been evaluated and not investigated the impact of information costs on the efficiency of making decisions. However, the calculation of costs for information services, which are also provided by the accounting system, is an important factor given the ability to optimize the preparation of information. To characterize the current stage of the development of the economy, the next concepts as "information economy","economy of knowledge","Internet-economy","post-industrial economy" and "innovation economy" have been compared. The investigation gave the possibility to define that information and post-industrial economy are synonyms - the concept "post-industrial economy" characterizes the same stage of the development but from the retrospective point of view. Such concepts as "knowledge economy", "Internet economy", and "innovation economy" are components of the information economy, which form its characteristic features. Nowadays, information plays an important role for a manager and influences the activity of an enterprise. The experience of successful companies shows that their achievements depend on the well-organized information system. Practical implications. Thus, the considerable part of information (78.5\%) provided for managers belongs to business accounting that intensifies its role at an enterprise in the information economy. Value/originality. It could not be overestimated the meaning of full and true information about the financial state and the results of the activity of an enterprise to solve current and prospective financial and economic problems.
\end{abstract}

Key words: information, information economy, information society, accounting system, business accounting system, processing plant, management, concept.

JEL Classification: M42, M49

\section{Introduction}

Transition to information output expansion and realization of information products and services change the location and prospects of the country in the world economy, supports its technological independence, increases compatibility that causes the actuality of forming and developing the information market, and exacerbates the problem of information support of the modern stage of economic development. At the modern stage, information product and services become strategic resources for economic development. A considerable role of information is in the financial business, where the decision making is based on punctual and reliable information what defines a high

\footnotetext{
Corresponding author:

${ }^{1}$ Ternopil National Economic University, Ukraine.

E-mail:v.ruzheliuk@tneu.edu.ua

2 Ternopil National Economic University, Ukraine.

E-mail:v.semaniuk@tneu.edu.ua

${ }^{3}$ Ternopil National Economic University, Ukraine.

E-mail: burdeniuk@tneu.edu.ua
}

efficiency of such a decision and sometimes it can cause considerable losses.

The main principle of a new paradigm of the information society is an orientation on intellectual, artistic, and creative potential. The global information society is a society of mental work, which is based on the use of knowledge in all spheres of human activity production, science, and education.

From the second half of the $20^{\text {th }}$ century, one can observe features and tendencies of forming an information society that causes forming new objects of business accounting. This stage differs from "traditional" industrial economy by its essential displacement of the used human resources from tangible to intangible, 
increasing transactional sector and blurring of borders between branch markets.

\section{The genesis of development of the information economy in the modern world of business}

Modern highly developed countries enter a new historical stage of the development of civilization post-industrial, information type of the development of society. Different types of knowledge and information become the main factors in the development of such a society. They support the increase of impact on all spheres of human activity - production, education, culture, leisure and, first of all, management system.

P. Drucker suggests that the main goal in business management is creating wealth but not control costs, what should be implemented in modern management concepts (Drucker, 2004). To manage effectively, one should predict the future. The true prediction can be supported by a deep retrospective analysis of rules of course of past processes.

The information economy is a term used during the 1970s-1980s when a big part of GDP was supported by production, processing, storage, and dissemination of information and knowledge. The majority of people occupied in this activity, where electronic and information means of connection are used in the development of all main economic means. Besides, the information itself is identified as products and investigated using statistic methods.
Characteristic peculiarities of information society are depicted in Figure 1.

Therefore, we can affirm that in the last quarter of the $20^{\text {th }}$ century, the humankind entered a new stage of its development - information society. Economic information should be emphasized because it is very useful for people who deal with accounting information, which is called by A. Barkhatov as "economic chronicle" (Barkhatov, 2001)

Information in management is interpreted as the aggregate of data necessary for an active influence on the managed system to optimize it. The usefulness and efficiency of information in such a case is assessed according to its level of influence on the change of stage that presents the state of a managed social object.

The Nobel laureate J. Stiglitz states that the information economy is a fundamental change of the paradigm, which occupied the ruling positions in economic science. It essentially influenced the modern approach to economic problems, explained phenomena, changed views on the functioning of economic mechanism and caused the reinterpretation of an adequate role of a state in society. The information economy is also called the economy of knowledge (Stiglitz, 2005)

It defines the necessity to determine and differentiate "information" and "knowledge". Undoubtedly, information and knowledge are connected concepts but the difference is fundamental. H. Demsetz built such a logical chain: information creates a productive field for innovations stimulating the production of new knowledge that supports optimization of the location of

The society, where production and consumption of information is the most important type of activity, information is considered the most important resource, new information, telecommunication technologies become the basic ones, and information surrounding among social and ecological become a new surrounding for human life.

The society, where knowledge is the main product. Distinct features of information society are the next: accessibility of necessary information for all members of society, the ability of society to produce all necessary information and support all members of society by means of access to this information

The level of social development, which is characterized by increase in the role of information and knowledge in social life; increase in the part of information communications, products, and services in GDP; creation of global information space that support effective information human interaction, their access to world information resources, and satisfaction of their social and personal needs in information products and services.

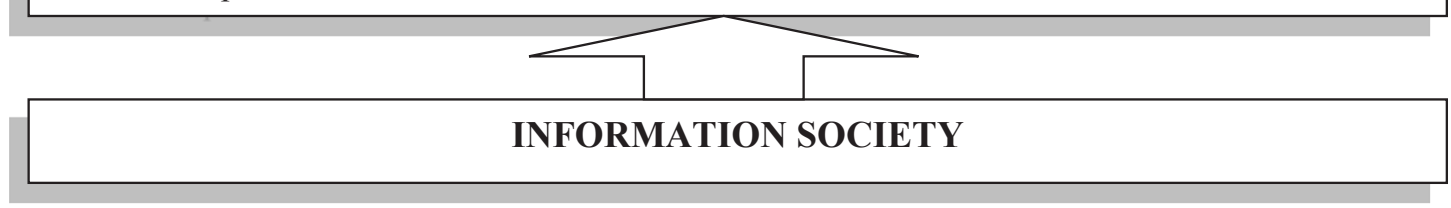

Figure 1. Definition of the concept "information society"

Source: developed by the authors 
physical resources and formation of other innovations (Demsetz, 1997). Investigating the stated above differences, M. Sheresheva suggested that "information economy" considers the current stage of social and economic development and "economy of knowledge" as the next stage (Sheresheva, 2008). It should be taken into consideration during forming the public economic policy of Ukraine that defines the longterm competitiveness of a country. Such an opinion can be true but we suggest that information economy, at the same time, characteristics of innovative and Internet-economy includes elements of the economy of knowledge (Figure 2). Therefore, the modern stage of the development of the economy should be called information, which includes the stated above aspects. To define it, we should investigate the use of the concept of a post-industrial economy, which is often found in scholars' works. O. Volkova and M. Denysenko wrote, "Information explosion, which has happened recently and transformed the industrial economy into information, has essentially changed all social processes" (Volkova, Denysenko 2004).

On the contrary, the production of tangible goods prevails in industrial society; in the information (postindustrial) society we can observe the production of intangible goods. Information makes essential changes in the world outlook of a human being and society.

Some scholars suggest that information is a function of time. L. Khoruzhii considered, "accounting of the reason of time is one of the obstacles to define information necessary for the future" (Khoruzhii, 2004). In H. Zakharchyshyn's opinion (Zakharchyshyn, 2012), information society widens space but restricts time stimulating the choice of priorities of activity. Taking into account this fact, we should talk not only about usual components of resource potential but should emphasize a new resource - time at the micro level to evaluate the efficiency of an enterprise.

\section{Information as a product of accounting system in the information society}

Current economic processes are characterized by swift information transfer about changes in branch markets so the decision about transactions can be taken in real time and transactions are made very quickly and practically twenty-four hours a day.

Usually, the advantages of information society are evident but the question is whether all its consequences were positive? F. Fukuyama is the first who put this question (Fukuyama, 2008). We should emphasize that there are many disadvantages to the information economy (Figure 3).

Information and knowledge as more powerful productive forces caused the gap in profit between the richest and poorest countries of the world up to 72:1 at the beginning of the $21^{\text {st }}$ century. During the last 25 years, it increased in 10 times. According to UNESCO data, $80 \%$ population on the Earth has only the basic education or does not have it at all, $85 \%$ have never used a telephone, and $93 \%$ have never used a computer (Chukhno, 2007).

Joseph E. Stiglitz stated that information economy much influenced our imagination about economic policy and it can have a bigger influence in future (Stiglitz, 2005). S. Kuznyetsova ascertained (Kuznyetsova, 2007), the strategic goal of the development of the information-based society is information-based economy in Ukraine. Besides, the issue of informationbased economy should be suggested in the context of economic entities, which use information.

Information economy changes not only characteristic of production and economic relations but also information technology, which has a direct influence on

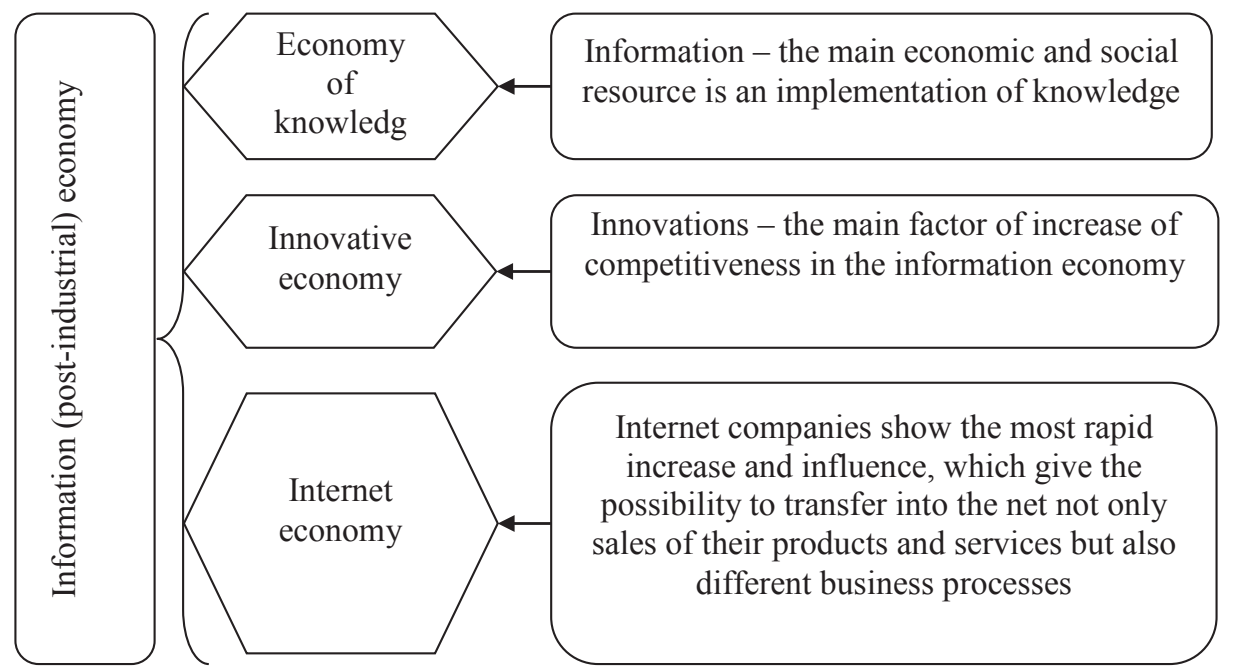

Figure 2. The main features of the information economy

Source: Rozhelyuk, 2013 


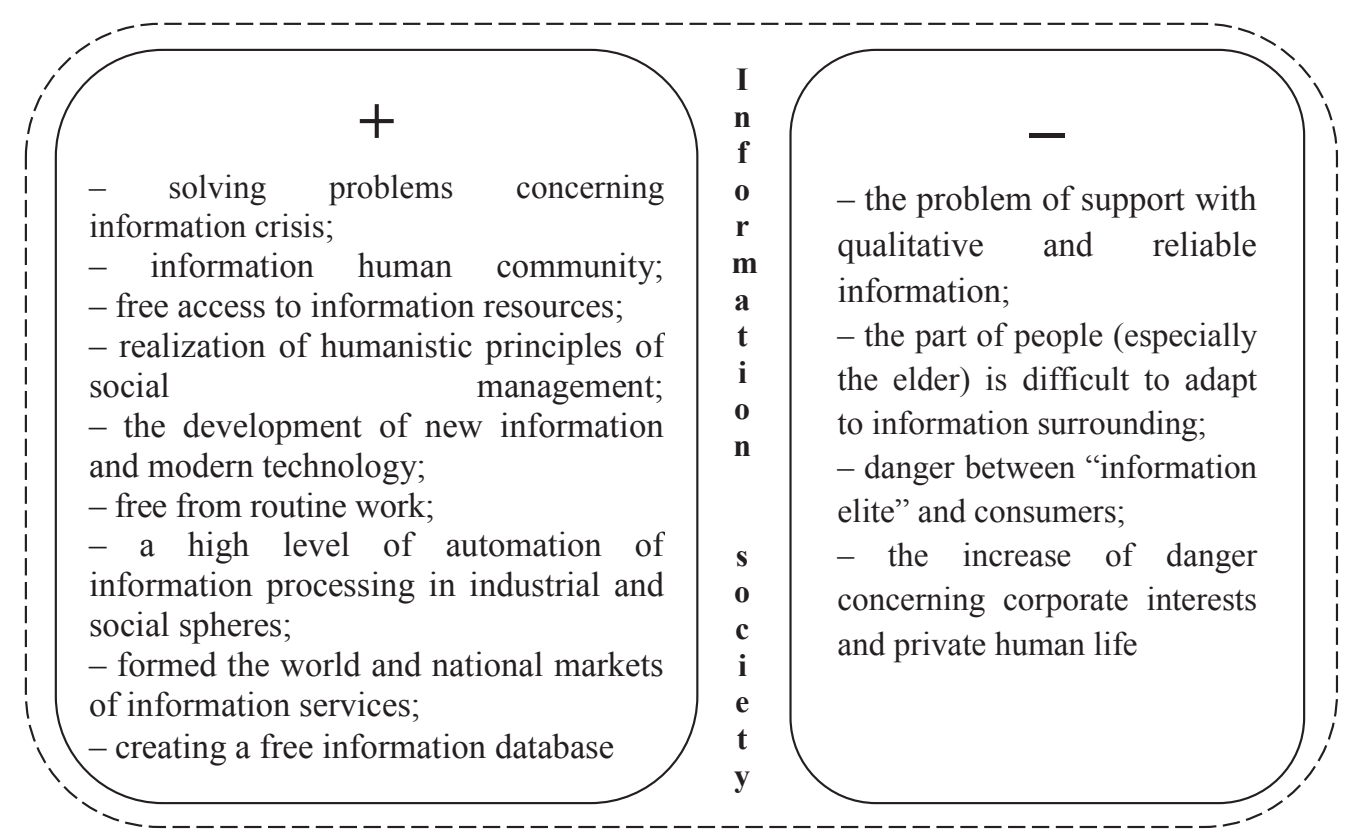

Figure 3. Positive and negative features of the information society

business accounting and that is the concept taken as the base of its theory (Figure 4).

Information should be differentiated from data and knowledge. Although, in some approaches, information is a generic concept for data and knowledge, which differ by a different stage of structural nature and understanding of information. For further investigation, we suggest defining the essence of the concept "information". Information is one of the actual, fundamental, and debate concept in modern science and practice. Because of the absence of a common definition, in different branches there are different interpretations of information. The following definitions, which are oftener used:

- information about persons, subjects, facts, events, phenomena, and processes, which are presented in any objective form that supports the possibility of its filing and dissemination;

- data, which was transformed from an italicized part of the text;
- knowledge (information) about such objects as facts, events, phenomena, subjects, processes, imagination, which include concepts having a concrete content in some context;

- block of knowledge, facts, information that is interested in and should be processed and recorded;

- results of reflection caused by any interaction between objects, information about anybody or anything able for support of active actions.

By general meaning of this word, information is not only what decreases the measure of the indifference of its user concerning any object. Talking about the object, we should understand something existing independently from our consciousness. Information is a reflection of an object in recipient's (subject) consciousness. It gives the possibility to define the quality of information (Petrenko, 2008).

W. Ashby considered information as diversity, at the same time C. Shannon understood it as not any data

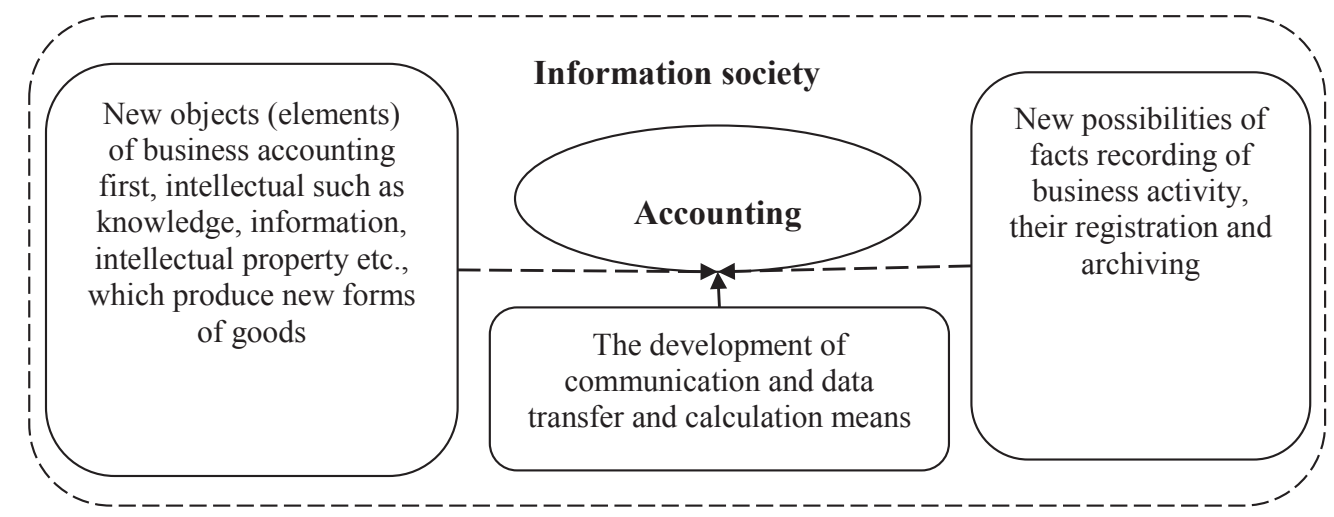

Figure 4. Information economy's influence on business accounting (Rozhelyuk, 2013) 
exchanged between people but only that decreasing the level of consumer's indifference (Ashby, 1962). The concept of indifference became the key in the investigation of information by C. Shannon, who stated that indifference could be only making the choice among two or some opportunities. Nowadays, the majority of scholars defining the concept of "information" use the concept "indifference" (Shannon 1963). Therefore, V. Petrovych (Petrovych, 2010) suggested that information can be defined as the "block of data decreasing the indifference of the perception of surrounding world". By a narrower meaning, information is data, which are an object of recording, dissemination, and processing" (Hnilitskyi, Orekhov, 2009).

Italian professor J. Galassi (Galassi, 2011) stated that the modern concept of information economy was developed from models of rational choice in the state of indifference. Besides, the scholar added that study of information and information systems, which is business accounting, is "beneficial base for interesting reveals, rich suggestion and prospect for the further development."

There is a view (Stiglitz, 2005) that information is a type of transactional costs. Many economists from Chicago school considered that information economy was suggested as a branch of applied economics. In S. Haluzina's opinion (Haluzina, 2006), accounting data are "raw materials" for creating information. We do not agree with this opinion because the system of business accounting includes data, indices, and information. Data are information, facts, values and their correlation, transformation and processing that give the possibility to receive information that is knowledge about a subject, process or phenomenon. The information contains only those data, which reduce the indifference of events interesting for the addressee, a user that is again received data and the quantity of information depends on the impossibility to predict them.

Therefore, the concept "information" is the concept that has a broad meaning. By information, we understand data, message, events or situations. It is disseminated and perceived as signals, that is why it is considered as any physical influence of material things or reflection of its influence, which has a concrete meaning. According to V. Sukhina (Sukhina, 1992), information can be defined as the measure of the arrangement of the material system. It is an information resource, that is, received knowledge and data about the state of the external and internal surrounding of the system are used in production and management as a factor to increase efficiency.

\section{Accounting information in management system at processing plants}

Requirements of information society make managers of enterprises to increase the quality of the system of business accounting that supports the quality of information support of internal control. However, it should be noted that the level of the quality of business accounting does not meet modern requirements of management.

It is necessary to define the terms and show the difference between "information" and "knowledge" that allows proving our understanding of essential differences between "information economy" as a modern stage of social and economic development and "economy of knowledge" as the next possible stage.

The origin of knowledge management can be observed in Plato's works. However, only recently, essential changes have been made in economy and business, which stimulated the interest to the given problem. Knowledge management is an aggregation of different subjects, different approaches, and concepts. Their main goal is to create new and more powerful competitive advantages for enterprises. Knowledge management predicts the creation of new knowledge and stimulation of its increase.

Theoretical base of knowledge management is: philosophy, psychology, pedagogy, sociology, logic, economics, management, marketing, management theory, informatics, and the whole range of applied economic, technical, and cross disciplines. Knowledge is the result of cognitive human activity, which is in the form of adopted concepts, laws, principles, and fixed samples of phenomena and subjects. It can be empiric, insufficient generalized, and theoretical that reflects natural connections and relations.

Knowledge should be differentiated from the data and information. It is more than simply information: knowhow - tested proved procedures; know-who - people having experience or resources; know-what - ability to differentiate and chose the key models and actual actions; know-why - understanding of the context of a big experience (view); know-when - combination of feelings of rhythms, time, and realism. The given concept is characterized by internal interpretation, structural and bound features, and mutual activity (Kandybovych, 2010).

Economy, like any activity of society, is based on information and at the modern stage of its development possession of knowledge and their usage are the main reason of economic development and the base of transformation processes. That is why, economic information is a special type of information, which is defined by L. Khoruzhii (Khoruzhii, 2004) as the aggregate available differences in the economic entity. These data should be fixed, transferred, processed, recorded, and used for management by an economic entity or its separate elements. Facts are the base for such data that is all data about used resources. It is impossible to manage an enterprise effectively without information processes. The law of information means that the level of management can be higher when there is new information and when this information is used. Therefore, in the accounting system, the law of information is active. 
Vol. 4, No. 4, 2018

Table 1

\section{Different types of knowledge described in the literature}

\begin{tabular}{|c|l|}
\hline Type of knowledge & \multicolumn{1}{c|}{ Essence } \\
\hline Implicit & $\begin{array}{l}\text { Personal knowledge connected with individual experience; skills, patterns of thinking, behaviour, intuition. } \\
\text { Implicit knowledge is in human minds, personal archives, on the contrary to explicit knowledge, it is personal, } \\
\text { with contextual meaning and that is why it is difficult to formalize it and transfer. }\end{array}$ \\
\hline Explicit & $\begin{array}{l}\text { Accumulated experience, which can be emphasized and presented in the form of reports, analyses, management, } \\
\text { instructions and recommendations for activity. This knowledge is easy to define, fix, record, and transfer using } \\
\text { information technology. }\end{array}$ \\
\hline Innovative & Unique knowledge, which supports a competitive advantage in the activity. They allow changing "rules of the game". \\
\hline
\end{tabular}

Source: developed by the author based on (Kandybovych, 2010; Kovalyov, 2004)

With a particular focus on differences between "information" and "knowledge", the author made a conclusion that the term "information economy" corresponds to the logic of the beginning stage of the social and economic development, which can be characterized as "information industrialism". The given stage differs from "traditional" industrial economy by essential improvement of used resources from material to immaterial ones by an increase of transnational sector and disappearance of borders between branch markets.

Forming information in business accounting, factors, which limit appropriate and reliable information, should be taken into consideration. Timeliness of information is one of such factors. Excessive delay of data submission to interested users can cause the loss of its relevance. Continuous waiting can support a high reliability of information but make it for small use. The use, which is received form formed in business information accounting, should be compared with expenses used for its preparation.

Any incorrect presentation of data in business accounting breaking the set of rules of its organization and conducting decreases sharply the value of accounting information. There are intentional and unintentional misrepresentations of reporting. Intentional misrepresentation is a result of deliberate actions (or inactivity) of staff of an enterprise. They are made with lucrative impulses to mislead the users of reporting. Unintentional misrepresentation of reporting is a result of unpremeditated actions (or passivity) of the staff of an enterprise. It can be the result of arithmetic or logical records, mistakes in calculations, oversight in accounting confidence, incorrect representation in the accounting of the fact of economic activity, property, and its condition.

Factors, which reflect the peculiarities of a state of a concrete branch of the activity of an enterprise in general that will support the appearance of misrepresentation, are the next:

- the state of the economy itself and economy of a country in general - crisis, depression or rise;

- age-specific possibilities of the rise of impossibility (bankruptcy) of economic entity because of the crisis of a branch;

- peculiarities of industrial activity of economic entity and technological peculiarities of production.
The reason for accounting unreliability can become unsuccessfully chosen accounting policy, a method of its use or inadequacy of information disclosure in accounting reporting.

Despite available disadvantages, the majority of the information needs of the business are systematized into management information systems under current conditions of social development. Management information system consists of interconnected subsystems, which provide information necessary to perform business. Accounting information system is the most important subsystem that is why it plays the main role in the management of economic information in all departments of an enterprise and for all users.

We suggest that under the conditions of constant complications of economic relations in society, as a rule, there are not one but some paths of achievement of the necessary result. Following each path, there will be a result that is the activity will be productive. However, not all paths to achieve the result will be optimal from the point of view of corresponding criteria, the movement to the result using not optimal path cannot be defined as effective. Therefore, we can make an important conclusion: any effective activity is successful but not any successful activity can be effective. Resulting character is a necessary but insufficient condition for effectiveness.

We should provide H. Emerson's expression about the role of business accounting (principle 6): "Such as there may be detailed and accurate bookkeeping, on its own it cannot create productivity. Its ideal components are: debit, credit and balance and availability of documents about each record. No norms, besides the norms, which were achieved in past, bookkeeping cannot show; the only unproductivity, which it can reveal is an achievement, not those results, which were achieved in past. Bookkeeping cannot either create productive norm or try to get them. However, no modern enterprise can work without bookkeeping" (Emerson, 1992). It is the best answer for those who consider that bookkeeping lost its meaning and even without making accounting procedures effective performance can be achieved. We can make the following conclusion: only that accounting system can be defined as effective, which owns synergy in full sense that is the maximal efficiency of common functioning of its elements. 
Thus, Pareto's law can be used as a basic set for the analysis of reasons of efficiency of any activity and optimization of its results. An adequate choice of minimal quantity of the most important actions gives the possibility to receive the considerable part of the full planned result, besides further improvements are not effective and unjustified (according to Pareto curve). The category of efficiency is very important and it is investigated by different scientific schools.

Management sets the valuable approach for business management, "Everybody should bring value. He who does not bring value then he sells it." Therefore, indications of KPI (Key Performance Indicators) should measure the efficiency of the work in each department or employee. It belongs to the accounting system.

Accumulated data in the information system are not necessary by themselves, they are valuable only then when they can be used for the managerial base of necessary decisions. Such decisions fall under some systematization, which allows arrangement of requirement presented for the volume and structure of data circulating in the information system (Figure 5).

Information from business accounting system is provided for users, which are divided into internal and external users. External users are considered to have a limited volume of information and internal ones - full. However, in modern conditions, when information is a subject for discussions, it is necessary to specify who users are, what are they, and what information requests they form.

Information, which is correspondent to ethical norms and is transparent and it is not created by managers, which try to present it better than it is in reality, is objective and reliable.

Users of all levels need information that is why there is an information base as the block of data, which is specific information raw materials, on the base of which information is formed. There are different definitions of information: as data, which decrease the indifference in some part to which they belong. Thus, information is new knowledge, which does not exist in new type by itself but a consumer of information raw materials, which is data, which potentially carry information, generate it.

\section{The business accounting system in information support at processing plants}

Business accounting is the base of information company support. Its main task is to support users with information about the business state.

The final accounting product is information necessary for taking management decisions and their monitoring. Accounting provides current information about the performed operation and final information about facts. The final product of accounting is information about facts about economic life during a month and quarter. Accounting objects are defined for these goals; methods for forming information are defined; specialists are appointed.

Therefore, accounting management supports creating necessary conditions for a management system in providing information for making management decisions and their monitoring.

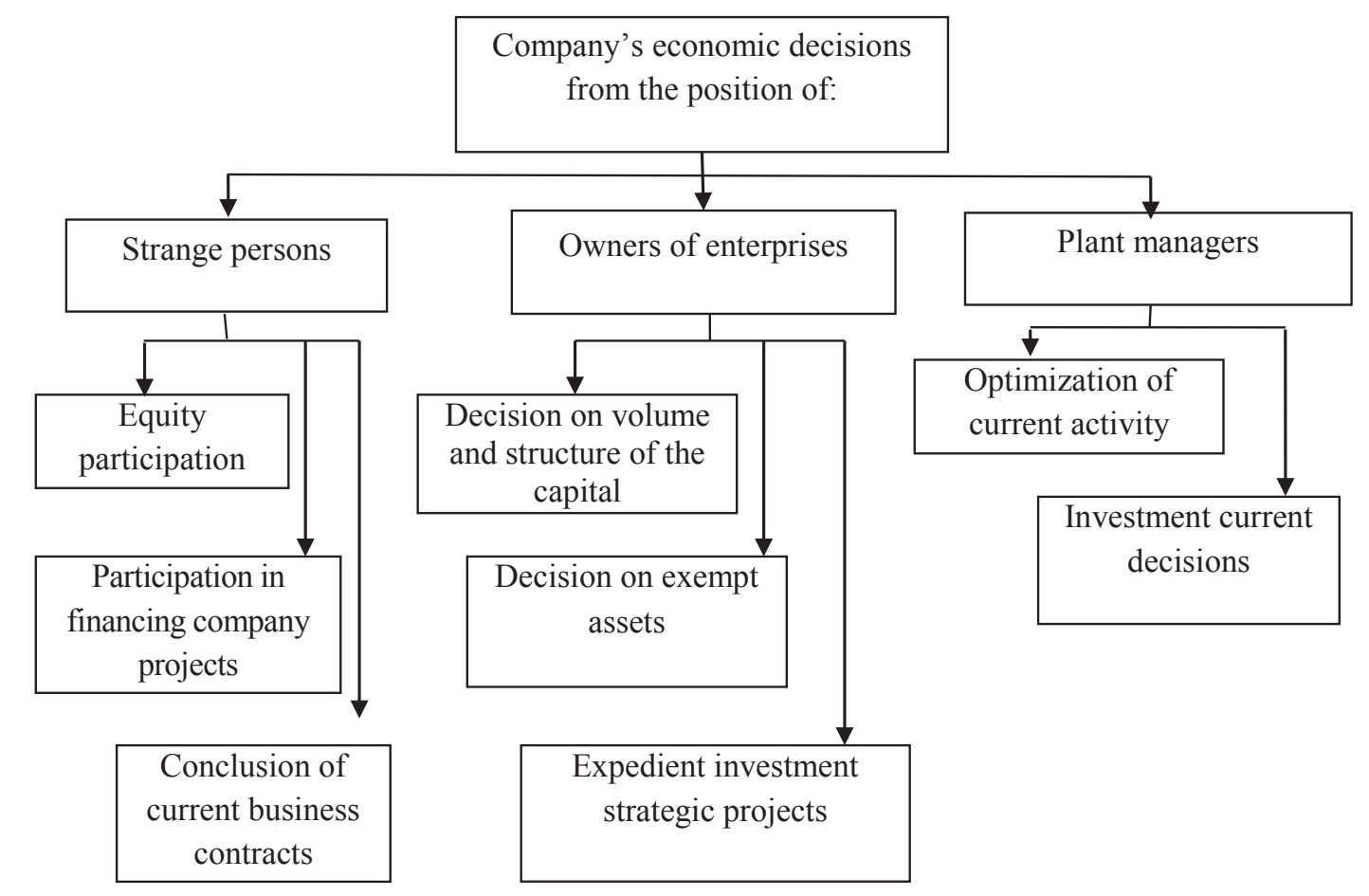

Figure 5. Company's economic decisions taken from different positions (interests) 
A financial report under market conditions is interested for two groups of users. Therefore, under the conditions of market economy, the set of users of report is wider than under the conditions of planned and administrative system, where the only internal and external user was a state or authority (ministries, fiscal bodies, statistic services) or manager of an enterprise, which was oriented on the fulfilment of state plans and tasks.

Paying attention to that fact that users' interests are different, business accounting cannot satisfy all information needs. Formed information in business accounting for external users satisfies general needs.

Business accounting does not reflect only facts but information about them. Data about separate facts are transformed in the accounting system into information economic characteristic. Correct and effective accounting gives the possibility to consider that on all stages of the accounting process, only that information is fixed and integrated, which is necessary for business management (Nakonechna, 2009). External users are provided with not full information and they cannot see a broad picture of the business.

Taking into consideration the main task of business accounting, we can suggest that business accounting management is data collection management, their processing, and delivery of information. Quantity, quality, and direction of the generated information are specified by life that is by business activity. During the whole period of existence of accounting, information was divided into good and bad (is not correspondent to requirements).

Information economy's influence on business accounting system - a rapid development of computer technology and software development should be emphasized.

It was proved that since the beginning of the second half of the $20^{\text {th }}$ century, as many famous scholars predicted that information stage of social and economic development has come. This type of the economy is retrospectively called post-industrial and it involves aspects of Internet economy, knowledge economy, and innovation economy. Besides, information is processed data (including business accounting system), which decrease users' indifference. Moreover, it should be taken into consideration that in accounting management, modern economic processes require processing of more volume of information for different types of users.

Therefore, information for management is provided by not only the accounting system but also management control and analysis, which use accounting data. According to different assessments, accounting provides $70-80 \%$ of the information and the rest of it is provided by other functional services of an enterprise. Company accounting section creates a product - information, which is always in great demand that requires the development and implementation of accounting management in the information economy.

\section{Conclusions}

The research of the role of business accounting as information system under the conditions of the settling of information economy gives the reasons to affirm that under the conditions of the information society, time element plays a very important role. In fact, nowadays, information loses its actuality; its value can be varied depending on the time that is why time element is determinant in business in providing a business accounting as an information producer. The business accounting system should be organized to provide necessary time-effective information with minimum expenses of efforts.

A systematic approach in investigations, new technology, and information orientation of society created a base for the development of a new business accounting management. We agree with the opinion of many scholars, which consider business accounting as an information system because in business accounting, all its components systematically interact and each of them has qualities. Their exclusion decreases general potential and efficiency of the information system. Only in totality, they form information system, on which financial and economic activity of an enterprise depends.

Proceeding from modern social and economic conditions, scientific and technical progress, and an increase of the volume of information, which should be processed at enterprises, institutions, and organizations of Ukraine, a computer-based form of business accounting is widely used. In spite of its disadvantages, the system simplifies accountant work and increases the speed and time of inquiry execution.

General criteria of quality can be the correspondence of accounting information to requirements of national and international standards. However, each business entity should develop its own criteria of qualitative accounting information, the features of which are the following: sufficient content, reliability, structural, true, analytical, stable, comparative, accurate, fresh, legal, appropriate, done in time, understandable and confident character.

Therefore, experimental results gave the possibility to investigate a significant problem in the discontent of accounting information management needs. Besides, incorrect accounting system management is the reason for dissatisfaction. On the one hand, managers do not know what information can be provided by the accounting system and on the other hand, their information request enquires a lot of time and efforts. Altogether, if done right, such problems could be avoided if the information in accounting is formed to receive it easily without many efforts for the processing of unnecessary information. Organizing business accounting system, it should be taken into consideration that it is not preferred to increase processed information content but it is necessary to optimize technology of processing of necessary and important information and be able to separate irrelevant information. 


\section{References:}

Drucker, Peter (2004). Encyclopedia of management: translated form English, Izdatelskij Dom "Vilyams”, Moscow, 432 p. (in Russian)

Barkhatov, A. P. (2001). International accounting: a textbook, Izdatelsko-knigotorgovyj Centr “Marketing”, Moscow, 228 p. (in Russian)

Stiglits, J. (2005). Information and change of paradigm in economic science, Mirovaya ehkonomicheskaya mysl. skvoz prizmu vekov. $\mathrm{V} 5 \mathrm{t}$. [World economic View. in the retrospect of time: 5 Vol.], in Fetisov, H. \& Khudokormov, A. (Eds.), Voskhodyashchij kapitalizm, Mysli, Moscow, 813 p. (in Russian)

Demsetz, Harold (1997). The Firm in Economic Theory: A Quiet Revolution American Economic Review, 87, 2.

Sheresheva, M. Yu. (2008). Correlation of concepts "Information Economy" and knowledge economy. Vestnik Moskovskogo Universiteta, 5, 24-31. (in Russian)

Volkov, O. I., Denysenko, M. P., Hrechan, A. P. \& others (2004). Economy and innovation activity management: a textbook, in Volkova, O. I. \& Denysenko, O. I. (Eds.), VD “Profesional”, Kyiv, 960 p. (in Ukrainian)

Khoruzhyi, L. I. (2004). Issues on theory, methodology and organization of accounting management in agriculture. Finansy i statistika, Moscow, 496 p. (in Russian)

Zakharchyshyn, H. M. (2012). Integrated perspective of innovative issues in information society. Aktualni Problemy, 12(138), 10-15. (in Ukrainian)

Fukuyama, F. (2008). A Big Gap, Translated from English, in Aleksandrova, L.V. (Ed.), AST: AST MOSCVA, Moscow, 474 p. (in Russian)

Chukhno, A. A. (Ed.) (2007). Modern economic theories: a textbook, Znannya, Kyiv, 878 p. (in Ukrainian)

Kuzntetsova, S. A. (2007). Methodological base of business accounting transformation as the direction of the development of information-based society, Bukhhalterskyi oblik $i$ audit, 7, 23-27.

Rozhelyuk, V. M. (2013). Business accounting management at processing plants: a monograph, NNTs IAE, Kyiv, 488 p. (in Ukrainian)

Principles of Self-Organizing Systems, in Heinz Von Foerster and George W. Zopf, Jr. (Eds.), Principles of SelfOrganization (Sponsored by Information Systems Branch, US Office of Naval Research), 1962.

Shennon, K. (1963). Papers in information theory and cybernetics, IL, Moscow, 830 p. (in Russian)

Petrovych, M. V. (2010). Company management: a manual. Akad. upr. pri Presidente Resp. Belarus, Minsk, 331 p. (in Russian)

Hnilitskyi, V. V. (2009). Information protection: a manual for students of economic specialties. IMIDZH, Zhytomyr, $164 \mathrm{p}$.

Halassi, J. (2011). The main principles of information economy, taking decisions and Italian theory of business activity. International Scientific Conference "Sokolov Reading". Look from Past into the Future. February/10-11/2011: Theses, SPb.: Published House at Saint Petersburg University, 156 p. (in Ukrainian)

Haluzina, S. M. (2006). Aspects of the promotion of the role of accounting and analytical information under the system of company management: a monograph. SPb. Znanie, Saint Petersburg, 392 p. (in Russian)

Sukhina, V. F. (1992). A man in the world of informatics. Radio i Svyaz, Moscow, 111 p. (in Russian)

Kandybovych, L. A. (2010). Knowledge management. Terminological Dictionary-Guide, Kharvest, Minsk, 752 p. (in Russian)

Khoruzhyi, L. I. (2004). Issues on theory, methodology and organization of accounting management in agriculture. Finansy i statistika, Moscow, 496 p. (in Russian)

Kovalev, V. V. (2004). Financial accounting and analysis: concept base. Finansy i statistika, Moscow, 720 p. (in Russian)

Emerson, H. (1992). Twelve principles of production. Ekonomika, Moscow, 112 p. (in Russian)

Nakonechna, N. V. (2009). Conceptualization of accounting systems, Naukovyi visnyk NLTU Ukrainy, 19.4, 191-198. (in Ukrainian) 